\title{
„Spokojnie, jestem grzeczny”. Molestowanie seksualne jako strategia uczestników badania
}

\author{
Alicja Palęcka \\ Uniwersytet Warszawski
}

DOI: https://doi.org/10.18778/1733-8069.17.2.03

Słowa kluczowe: molestowanie seksualne, teren badawczy, kultura akademicka, strategie osób badanych

\begin{abstract}
Abstrakt: Celem artykułu jest uwidocznienie przemocy doświadczanej w terenie przez badaczki i badaczy. Po pierwsze, przemoc bywa częścią pracy w terenie i jako taka może podlegać analizie. Po drugie, przemilczanie jej wzmacnia szkodliwe aspekty kultury akademickiej, w której problemy związane z przynależnością do grup mniejszościowych (w tym problemy kobiet w akademii) pozostają niewidoczne. W konsekwencji instytucje badawcze nie wypracowują mechanizmów wsparcia dla osób doświadczających przemocy, a badacze i badaczki nie są przygotowane na tego rodzaju trudności. Analizuję trzy przy padki molestowania seksualnego, którego doświadczyłam w terenie. Interpretuję je jako jedną ze strategii przyjmowanych przez uczestników badań podczas wywiadu dla zyskania władzy lub kontroli nad sytuacją.
\end{abstract}

Alicja Palęcka, mgr, doktorantka w Katedrze Socjologii Ekonomicznej i Spraw Publicznych na Wydziale Socjologii Uniwersytetu Warszawskiego, gdzie realizuje badanie dotyczące norm i znaczenia pracy. Zajmuje się socjologią pracy i etyką badań jakościowych. Współorganizatorka Spotkań Badaczek przy WS UW.

\section{Adres kontaktowy:}

Katedra Socjologii Ekonomicznej i Spraw Publicznych

Wydział Socjologii, Uniwersytet Warszawski

ul. Karowa 18, 00-927 Warszawa

pokój 306

e-mail: a.palecka@is.uw.edu.pl

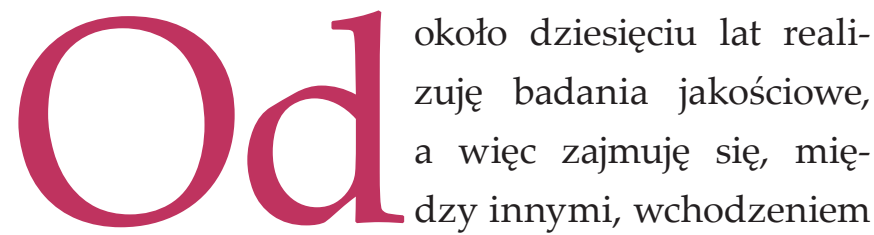
w relacje z ludźmi. Relacje te trwają zazwyczaj zaledwie kilka godzin, jedynie czasami kilka dni, tygodni lub miesięcy. Zawsze jednak wymagają uważności i ostrożności oraz swego rodzaju zarządzania zakresem kontroli i sprawczości obu stron spotkania w dążeniu do relacji równej, partnerskiej. W artykule $^{1}$ opisuję trzy sytuacje, w których utraciłam

1 Artykuł powstał w ramach projektów finansowanych przez Narodowe Centrum Nauki: „Negocjowanie norm 
kontrolę i sprawczość na rzecz rozmówców - mężczyzn, którzy molestowali mnie seksualnie podczas wywiadów. Molestowanie interpretuję jako strategię oporu mężczyzn, uczestników badań, wobec sytuacji badania, w której zazwyczaj to badaczka ma więcej kontroli. Ta męska strategia możliwa jest dzięki nierównym pozycjom badaczki i rozmówcy w hierarchii płci.

Celem tego artykułu jest wskazanie przemocy, zwłaszcza przemocy seksualnej, jako jednego z problemów, z którymi mierzą się badaczki i badacze w terenie. Polskojęzyczne refleksyjne omówienia praktycznych i etycznych trudności badań jakościowych, w których problematyzowane są tożsamości i pozycja badaczek i badaczy, pojawiają się regularnie między innymi na łamach tego czasopisma (np. Męcfal 2016; Surmiak 2016; Golczyńska-Grondas 2019). Molestowanie seksualne w terenie nie zostało jednak do tej pory omówione w polskojęzycznej literaturze socjologicznej. Tymczasem przemoc seksualna jest jednym z ryzyk, na które badaczki jakościowe są wystawione w swojej codziennej pracy. To, jak sobie z nim radzą, jest uzależnione nie tylko od ich osobistych umiejętności i dyspozycji, ale też od środowiska zawodowego, w którym funkcjonują oraz od przygotowania instytucji badawczych do wspierania osób doświadczających przemocy w pracy.

W ujęciu, które przyjmuję, przemoc seksualna jest sankcją stosowaną przez mężczyzn dla przywracania i utrwalania patriarchalnego porządku, zmuszania kobiet do przestrzegania narzuconych im ogra-

pracy w instytucjach rynku pracy w Polsce. Perspektywa osób bezrobotnych" (2018/31/N/HS6/01964) oraz „Technologie informacyjne w polityce publicznej. Krytyczna analiza profilowania bezrobotnych w Polsce" (2016/23/B/ HS5/00889). niczeń2 (Moreno 19953). Ekstremalnymi formami przemocy seksualnej są gwałt i zabójstwo. Przemocą seksualną jest także molestowanie seksualne, to jest zachowania - takie jak wypowiedzi, gesty, działania - o konotacjach seksualnych, które powodują zastraszenie i poniżenie innej osoby, dając sprawcy władzę nad nią. Niesymetryczność relacji i nierówność władzy są istotnymi warunkami molestowania seksualnego, a społeczna kontrola, utrzymanie hierarchii opartej na płci oraz podporządkowanie sobie ofiary przez sprawcę są rzeczywistym celem takiego zachowania (Kloß 2017). Często przyjmuje ono pozory flirtu, w którym jednak strona podporządkowana nie ma swobody wyboru, by flirt odwzajemnić lub nie (Kubisa 2005). W sytuacjach, które opisuję w artykule, doświadczyłam werbalnego molestowania seksualnego. Pod pozorem flirtu mężczyźni uzyskiwali lub umacniali swoją władzę i kontrolę, ograniczając mój wybór: mogłam kontynuować badanie pod warunkiem podjęcia flirtu na ich zasadach lub wycofać się.

Moje trzy doświadczenia, które opiszę poniżej, były zarazem wyjątkowe i przewidywalne. Do tej pory

\footnotetext{
${ }^{2}$ Przemoc seksualna, tak jak przemoc w ogóle, występuje także w relacjach innych niż między mężczyznami i kobietami, a kobiety są także sprawczyniami przemocy, w tym seksualnej. Jest to jednak przede wszystkim jedno z narzędzi utrzymywania hierarchii płci. To osadzenie w kulturze patriarchalnej i związanej z nią władzą mężczyzn i podporządkowaniem kobiet jest szczególnie istotne i analitycznie efektywne z perspektywy niniejszego tekstu. Zazwyczaj więc w tekście używam rodzaju żeńskiego, kiedy mowa jest o osobach, przeciwko którym wymierzone jest molestowanie seksualne. W kilku miejscach używam także rodzaju męskiego, aby podkreślić, że mężczyźni także bywają narażeni na przemoc $\mathrm{w}$ terenie.

${ }^{3}$ Dojmującym i wymownym przykładem narzucania takich ograniczeń jest historia cytowanej autorki. „Eva Moreno” to pseudonim przyjęty na potrzeby publikacji, w której antropolożka opisuje gwałt, którego doświadczyła w terenie. Gwałcicielem był jej lokalny asystent. Pseudonim przyjęła nie po to, aby ukryć swoją tożsamość, była bowiem gotowa pisać pod własnym imieniem i nazwiskiem. Została zmuszona do przyjęcia pseudonimu przez wydawcę, który obawiał się pozwu ze strony gwałciciela.
} 
przeprowadziłam kilkadziesiąt wywiadów z mężczyznami (z około dwustu wywiadów w ogóle w mojej historii zawodowej), na ogół udawało mi się zbudować z rozmówcami partnerskie relacje, a ja byłam traktowana przez nich jak profesjonalistka w pracy (wyjąwszy sporadyczne przypadki tłumaczyzmu ${ }^{4}$ ) lub osoba, która dała im możliwość swobodnego opowiedzenia o sobie i bycia uważnie wysłuchanym. Zazwyczaj więc wywiady z mężczyznami są sytuacjami bezpiecznymi czy neutralnymi. Jednakże wywiady kobiet z mężczyznami często wiążą się z antycypowaniem zagrożenia lub seksizmu. Część badaczek ma odruch zastanawiania się nad środkami bezpieczeństwa lub przyjmowania wyprzedzających strategii, które mają niebezpieczeństwu lub seksizmowi zapobiec (Gearing 1995; Mügge 2013; Kloß 2017; Wojnicka 2020).

Trudne, przemocowe interakcje $\mathrm{w}$ terenie bywają rozumiane jako prywatny problem, bez związ$\mathrm{ku} \mathrm{z}$ przedmiotem badania i są zupełnie pomijane $\mathrm{w}$ pisarstwie akademickim lub relegowane do załączników metodologicznych. Tymczasem nasze relacje z badanymi, także te, które wymykają się spod kontroli, są elementem terenu, ich dynamika wnosi informacje o przedmiocie badania (Kloß 2017; Hanson, Richards 2019). To, jak przebiegają nasze kontakty z uczestnikami i uczestniczkami badania, ma też znaczenie dla jego wyników: sympatia, antypatia lub wrogość wobec osób udzielających wywiadów wpływają na naszą interpretację ich wypowiedzi (Stacey 1988; Ribbens 1989; Fine 1993). Pewne możliwości w terenie otwierają się, inne zamykają wraz z rozwojem relacji z ludźmi, z naszym samopoczu-

\footnotetext{
${ }^{4}$ Tłumaczyzm, czyli mansplaining (tłumaczony na polski także jako „panjaśnienie”), to protekcjonalne objaśnianie czegoś przez mężczyznę kobiecie, zwłaszcza w sytuacji, kiedy kobieta dostatecznie zna się na danym temacie, by nie potrzebować wyjaśnień. Termin został ukuty pod wpływem eseju R. Solnit (2017).
}

ciem $\mathrm{w}$ tych relacjach, $\mathrm{w}$ tym poczuciem zagrożenia (Moreno 1995; Mügge 2013; Hanson, Richards 2017).

Sytuacje, które opisuję, wydarzyły się w trakcie realizacji trzech różnych projektów badawczych. Chronologicznie pierwsza z nich (opisuję ją jednak jako ostatnią) miała miejsce w 2013 roku podczas realizacji badania, którego celem było zmapowanie grup zagrożonych wykluczeniem oraz analiza wymiarów wykluczenia społecznego z perspektywy społeczności lokalnych. W ramach badania prowadziłyśmy między innymi wywiady biograficzne $\mathrm{z}$ osobami należącymi do takich grup. Jednym z rozmówców był Jacek ${ }^{5}$, wytypowany ze względu na trudności na rynku pracy spowodowane poważnymi problemami zdrowotnymi. Kolejny wywiad, który opisuję, to rozmowa z Krzysztofem, która odbyła się w ramach badania funkcjonowania urzędów pracy, prowadzonego w latach 2018-2019. Wywiady prowadziłam między innymi z personelem instytucji rynku pracy, w tym z kierownikami urzędów pracy, a Krzysztof był jednym z nich. W obu projektach byłam wykonawczynią pracującą w większych zespołach, choć w teren jeździłam zazwyczaj sama. Natomiast ostatnia z opisywanych sytuacji wydarzyła się w toku współpracy z Bogdanem, którą nawiązałam w ramach własnych badań do pracy doktorskiej. Zajmuję się w nich etnografią bezrobocia skoncentrowaną na znaczeniach przypisywanych pracy, a badanie obejmuje między innymi wielokrotne wywiady z osobami bezrobotnymi. Projekt rozpoczęłam w 2018 roku i trwa on nadal. $\mathrm{W}$ tamtym czasie realizowałam go samodzielnie.

Jedynie ostatni z wymienionych projektów prowadzony jest $\mathrm{w}$ metodologii feministycznej ( $\mathrm{w}$ tym wypadku jest to etnografia instytucjonalna Do-

5 Imiona mężczyzn zostały zmienione. 
rothy Smith [2005]). W przypadku dwóch pozostałych, realizowanych $\mathrm{w}$ innych paradygmatach, można jednak mówić o feministycznym podejściu do realizacji wywiadów, zmierzającym ku opisanemu niżej modelowi (Oakley 1981). Wynikało to z moich własnych dyspozycji i przekonań dotyczących właściwego sposobu budowania relacji z osobami uczestniczącymi w badaniach, jak i, ogólnie, upowszechnienia elementów metod feministycznych w etnografii (jak wzajemność, refleksyjność, zwłaszcza dotycząca usytuowania, uwzględnienie emocji i relacji). Miało to, jak sądzę, znaczenie dla przebiegu interakcji z mężczyznami udzielającymi wywiadów.

\section{Etnografia i płeć}

Płeć jako istotna cecha osób prowadzących i udzielających wywiad została zauważona przez badaczki feministyczne. W swoim klasycznym tekście Ann Oakley (1981) problematyzuje tradycyjne, pozytywistyczne założenia dotyczące prowadzenia wywiadu, znane z podręczników metod i technik badawczych tamtego czasu: racjonalność, neutralność i "przezroczystośćc badacza, podporządkowanie tworzącej się podczas wywiadu relacji celom badania (a nawet zupełne niedostrzeżenie istnienia tychże relacji). Oakley zauważa, że taki model badań jest nie tylko nieetyczny, ale i niemożliwy do realizacji. Nieetyczny, gdyż czyni z „respondenta” źródło danych, które, odpowiednio obsługiwane, będzie te dane udostępniać w sposób pożyteczny dla projektu. Nierealistyczny i niemożliwy, bo podczas wywiadów nieuchronnie budujemy relacje. Szczególna więź ma według Oakley powstawać między dwiema kobietami. Wspólne dla nich doświadczenie podporządkowania męskiej dominacji jest źródłem porozumienia między badaczką a kobietą udzielającą wywiadu.
Analizując własne relacje z uczestniczkami badania o macierzyństwie, Oakley łatwo doszła do wniosków o łączącym je $\mathrm{z}$ nimi siostrzeństwie i wynikających z niego zobowiązaniach. Były one zaprzeczeniem pozytywistycznego, męskiego modelu opisanego wyżej i dotyczyły pielęgnowania, zamiast wypierania, relacji $\mathrm{z}$ osobami uczestniczącymi w badaniach. Osoby realizujące badania feministyczne powinny więc być otwarte na przyjaźń, bliskość i wzajemność z uczestnikami i uczestniczkami swoich badań, odpowiadać na zadawane przez nie pytania, a więc prowadzić rozmowę, zamiast narzucać jednokierunkową komunikację. Ponieważ strukturalnie mają władzę w sytuacji wywiadu (kontrolują jego tematykę, przebieg, interpretację i upowszechnienie wyników), powinny dzielić się kontrolą nad sytuacją, na przykład oddając decyzję o czasie i miejscu wywiadu. Właśnie spotykanie się w miejscach wybranych przez uczestników badania, często w ich domach, gdzie czują się swobodnie i gdzie badaczki są gośćmi, stało się domyślnym rozwiązaniem (Finch 1984; Limerick, Burgess-Limerick, Grace 1996; Yassour-Borochowitz 2012; Grębecka 2016).

Stanowisko Oakley, później krytykowane jako naiwne i pomijające między innymi intersekcjonalność (Riessman 1987; Ribbens 1989; Edwards 1990; Tang 2002; podsumowanie krytyki w: Oakley 2015), dało początek długiej dyskusji o prowadzeniu przez kobiety wywiadów z kobietami. Kolejne socjolożki przytaczały relacje z własnych badań, w których intymność i przyjaźń okazywały się nie tylko problematyczne lub niechętnie przyjmowane przez rozmówców i rozmówczynie, ale też niebezpieczne. Cotterill (1992) zniuansowała założenia o siostrzeństwie i o strukturalnej przewadze badaczki nad badanymi kobietami. Jej rozmowy z teściowymi - kobietami starszymi od niej i często o wyższym 
statusie, postawiły ją w sytuacji, kiedy to rozmówczynie miały kontrolę nad wywiadami i wykorzystywały ją do stawiania granic intymności i poufałości. Stacey (1988) sproblematyzowała postulat otwarcia się na długotrwałe relacje i przyjaźnie z badanymi, zauważając, że badaczka pozostaje osobą z zewnątrz, która ma możliwość wyjścia z terenu w dowolnym momencie, porzucając badanych, niezależnie od tego, że wcześniej zbudowała z nimi silną więź. Ta możliwość wyjścia czyni przyjaźnie zawarte $\mathrm{w}$ terenie relacjami nierównymi.

Założenie o strukturalnej przewadze badaczki nad osobami badanymi było wielokrotnie podważone przede wszystkim przez te autorki, które analizowały swoje relacje z rozmówcami (mężczyznami) (Arendell 1997; Lee 1997; Pini 2005; Yassour-Borochowitz 2012). Dynamika tych relacji, podobnie jak badaczek z kobietami, ma swoje źródła w zewnętrznych strukturach i hierarchii płci: „,[n]ormy sytuacji wywiadu badawczego nie unieważniają i nie zastępują społecznych norm wynikających z hierarchii płci; role płciowe i związana z nimi praca pozostają obecne i dominujące [w sytuacji wywiadu]" (Arendell 1997: 363 [tłum. własne]; zob. też: Smart 1984 za: Lee 1997). Badaczki prowadzące wywiady z mężczyznami często więc znajdują się w sytuacji podporządkowania, przekraczania ich granic, a nawet zagrożenia. Część omówień takich wywiadów koncentruje się na doświadczanym $\mathrm{w}$ terenie molestowaniu seksualnym.

Literatura ta ma różnorodne cele i funkcje: terapeutyczną i łamania tabu (Kulick, Willson 1995), dzielenia się wskazówkami i strategiami unikania, negocjowania lub radzenia sobie z seksizmem i przemocą w terenie (Green i in. 1993; Sharp, Kremer 2006; Gailey, Prohaska 2011; Mügge 2013; Kloß 2017; Wojnicka 2020), rozważania implikacji, jakie sytuacje te mają dla procesu powstawania wiedzy (Arendell 1997; Pini 2005; Wojnicka 2020). Wiele z tych relacji pochodzi od młodych badaczek lub badaczek doświadczonych, które dopiero po latach potrafią opisać wymierzoną w nie przemoc lub trudne momenty lęku o własne bezpieczeństwo podczas realizacji badania doktorskiego (Moreno 1995; Yassour-Borochowitz 2012; Mügge 2013). Niedoświadczone badaczki, na przykład podczas ich studiów doktoranckich, wydają się szczególnie narażone na niebezpieczne konsekwencje nierównowagi sił między nimi a badanymi - na ich niekorzyść (Pollard 2009).

Od niedawna autorki zauważają, że opis indywidualnych doświadczeń $\mathrm{w}$ terenie to za mało i problematyzacji wymaga całe pole akademickie i dominujący usankcjonowany sposób uprawiania etnografii (Kulick 1995; Pollard 2009; Hanson, Richards 2017; 2019; Steffen 2017). Jeśli bowiem akademia nie eliminuje molestowania $\mathrm{w}$ miejscu pracy i w relacjach między wykładowcami a studentkami i studentami, nie daje też warunków i przygotowania do radzenia sobie z nim w terenie. Co więcej, Hanson i Richards (2017; 2019) odnajdują źródło problemu $\mathrm{w}$ dominującym modelu uprawiania etnografii, w pochodzących z męskiej, pozytywistycznej, kolonialnej przeszłości „etnograficznych fiksacjach”, to jest fetyszyzacji badań ryzykownych, intymnych i realizowanych samodzielnie. Model ten, właściwy dla antropologii, częściowo obecny jest także w socjologii, szczególnie kiedy wykorzystuje ona metodę etnograficzną. Samodzielna realizacja badań jest rytuałem, przez który przechodzą młodzi badacze i badaczki podczas studiów magisterskich i doktoranckich, jest to też domyślne założenie podczas planowania budżetów projektów. Po takim treningu bezpieczeństwo badaczki czy badacza staje się drugorzędne i podporządkowane imperatywowi 
zbierania danych za wszelką cenę. Często jest też podporządkowane komfortowi uczestnika badania oraz regule bliskości i intymności. Nieosiągnięcie intymności w terenie albo wycofanie się z powodu zagrożenia bywają przyczyną poczucia porażki i niedorastania do wzoru dobrych badań. W konsekwencji etnograficzne fiksacje są przyczyną wypierania negatywnych doświadczeń i przemilczania ich w dysertacjach i publikacjach. Cielesność jest usuwana $\mathrm{z}$ tekstu etnograficznego lub wpisywana w dominujący rodzaj opowieści o terenie, w której nie istnieje płeć (ale też np. kolor skóry). Wydaje się bowiem, że pewne wydarzenia, doświadczenia i słowa nie są dozwolone $\mathrm{w}$ pisarstwie akademickim (Yassour-Borochowitz 2012; Kloß 2017; Hanson, Richards 2019). Tabu obejmuje nie tylko doświadczenia kobiet, ale też osób nieheteronormatywnych, a więc tych, dla których seksualność i płeć nigdy nie są przezroczyste i nieproblematyczne (Newton 1993; Kulick 1995). Tabuizowana jest także przemoc seksualna wobec heteroseksualnych cis-mężczyzn' W konsekwencji trudne doświadczenia wynikające $\mathrm{z}$ usytuowania $\mathrm{w}$ hierarchii płci interpretowane są jako dotyczące "kobiet” (albo gejów, osób transpłciowych), nie „socjologów” czy „antropologów”:

Niebezpieczeństwo przemocy seksualnej może być częścią codziennego życia kobiet, ale nie wydaje się dotyczyć naszych profesjonalnych tożsamości, tożsamości „antropologa”. „Antropolog” nie jest napastowany lub gwałcony. Napastowana lub gwałcona jest kobieta. (Moreno 1995: 246 [tłum. własne])

Dorothy E. Smith opisała tę alienację autorek w naukach społecznych „rozdwojeniem świadomości” (bifurcated consciousness) (Smith 1990), jako stan,

\footnotetext{
${ }^{6}$ Osoba cispłciowa to osoba, której tożsamość płciowa jest zgodna z płcią przypisaną przy narodzinach (tj. osoba nie transpłciowa).
}

w którym prowadzą podwójne życie: kobiet i naukowców bez płci.

Trzydzieści lat później wszystkie powyższe twierdzenia wydają się znacznie mniej aktualne, mniejszościowe narracje znajdują coraz więcej miejsca i forów, na których mogą wybrzmieć. Coraz częstsze otwarte raportowanie przemocy seksualnej w terenie jest jednym ze wskaźników tej zmiany.

Proces ten zachodzi bardzo wolno w literaturze polskojęzycznej, raczej etnologicznej niż socjologicznej. Negocjacje ról płciowych, nierówności między płciami i związane $\mathrm{z}$ nią zagrożenia są przedmiotem refleksji metodologicznej między innymi antropolożek Renaty Hryciuk i Karoliny Bielenin-Lenczowskiej. Hryciuk (2009), znając relacje etnografek pracujących $\mathrm{w}$ odległych sobie kulturowo i geograficznie lokalizacjach, antycypuje zagrożenie i efekt, jaki jej płeć, kolor skóry, pochodzenie etniczne i status mogą mieć w terenie: badaczka spodziewała się, że w Meksyku będzie postrzegana jako „dostępna seksualnie cudzoziemka". Molestowania doświadcza jednak tylko przemieszczając się po mieście, a nie $\mathrm{w}$ kontakcie ze społecznością, w której prowadzi badanie. Osoby, z którymi ma tam kontakt, przyznają jej raczej „androgyniczny status profesjonalistki" i ,terapeutki", co daje jej dostęp zarówno do informatorek, jak i informatorów. Bielenin-Lenczowska relacjonuje z kolei trudności, jakich doświadczały jej studentki podczas badań w Macedonii, gdzie postrzegane były jako wyzwolone seksualnie kobiety łatwo ulegające wdziękom "temperamentnych południowców" (2015: 28). Choć stereotyp ten ułatwiał badaczkom skłonienie młodych mężczyzn do udzielania wywiadów, ograniczał zakres tematów, które mężczyźni ci chcieli w wywiadach poruszać do relacji płci. 
Płeć w badaniu jest poddawana refleksji, jednak autorki wstrzymują się przed użyciem terminu „molestowanie seksualne". Nader ostrożnie określają sposób, w jaki były traktowane przez mężczyzn podczas badań, mówiąc o „próbach molestowania” (Hryciuk 2009: 69), „zachowaniu, które można uznać za molestowanie" (Grębecka 2016: 309). Częściej jednak słowo „molestowanie” nie pada wcale. Mimo że socjolożki i etnolożki piszą o seksualności i płci, często zatrzymują się pomiędzy problematyzacją a normalizacją. „Adorowanie” lub dyskryminujące przekonania o rolach płciowych, według których oceniane były badaczki przez rozmówców, normalizowane są jako nieodzowny element terenu. Mogą stać się barierą w zbieraniu danych (na przykład przez niepoważne traktowanie badaczki, jej seksualizację, pominięcie jej profesjonalnej roli) lub materiałem badawczym (jak na przykład tyrada o prawidłowych, zgodnie z kulturą rozmówcy, rolach płciowych u Kość-Ryżko) (Bielenin-Lenczowska 2013; Kość-Ryżko 2013). Podobnie socjolożka Męcfal (2016), mimo że odnotowuje sytuacje, w których narzucano jej tradycyjne role płciowe, nie problematyzuje ich w ten sposób. Kiedy rozmówcy naciskają, by opłacić za nią rachunek w kawiarni lub restauracji, autorka dostrzega w tym trudność $\mathrm{w}$ realizacji własnego zobowiązania wobec badanych, nie decyduje się natomiast na interpretacje z perspektywy genderowej. Trzeba zaznaczyć, że przezroczystość takich zdarzeń (od podkreślania i utrwalania ról płciowych po molestowanie) może wynikać z różnorodnych przyczyn: z nieistotności tego rodzaju zdarzeń dla badania, stopnia wrażliwości i podatności na zranienie, z internalizacji tak zwanej heteronormy. Te same wydarzenia i zachowania są problematyczne dla jednych osób, a niezauważalne dla innych, a wynika to między innymi z różnorodności naszych uprzednich doświadczeń.

\section{Molestowanie seksualne w terenie: trzy przypadki}

Molestowanie seksualne, którego doświadczyłam $\mathrm{w}$ terenie, było za każdym razem molestowaniem słownym: były to niechciane, niestosowne i nachalne komentarze, sugestie i propozycje. Seksualny podtekst jest elementem definiującym molestowania seksualnego (w odróżnieniu od szerszego pojęcia molestowania i innych form przemocy). To, co jednak w nim najważniejsze i co stanowi o dotkliwości tego doświadczenia, to narzucenie władzy sprawcy i odebranie kontroli osobie molestowanej, niekiedy zupełne pozbawienie jej poczucia sprawczości, w miejsce którego pojawia się poczucie zagrożenia. Będąc molestowaną jako badaczka, doświadczyłam więc poczucia utraty sprawczości i kontroli na rzecz sprawców. Odbierali mi kontrolę nie tylko nad wywiadem, odmawiając uznania mojej roli jako profesjonalistki będącej w pracy, ale też kontrolę nad sytuacją w ogóle, nad własnym bezpieczeństwem i tożsamością. W sytuacji molestowania podczas prowadzenia badań doświadczamy rozdwojenia: „badaczka powinna być racjonalną profesjonalistką, nie przestraszoną kobietą" (Yassour-Borochowitz 2012: 409 [tłum. własne]). W takich chwilach jesteśmy jednak jedną i drugą. Tożsamości te są bardzo trudne do pogodzenia, równocześnie nie dając się rozdzielić.

Opis przypadków powinnam rozpocząć od wskazania własnej pozycji i strategii, jakie przyjmuję podczas wywiadów. Realizuję studia doktoranckie oraz pracuję na uczelniach w Warszawie. 10 lat po ukończeniu studiów magisterskich jestem często brana za młodszą niż jestem w rzeczywistości. Ta moja cecha i status studentki (mimo że studiów doktoranckich) nie kojarzą się z władzą (a raczej z podporządkowaniem), za to kojarzą się z niedo- 
świadczeniem i brakiem wiedzy, którą rozmówcy mają pomóc mi uzupełnić (McLuhan 2020). Wszystko to bywa użyteczne w skróceniu dystansu z rozmówcami i rozmówczyniami. Poza tym jestem konwencjonalnie atrakcyjna i zazwyczaj przypisywana jest mi orientacja heteroseksualna.

\section{Krzysztof: niepodzielna władza odźwiernego}

Krzysztof był dyrektorem urzędu pracy w dwudziestotysięcznym mieście B. W urzędzie tym przeprowadzałam szereg wywiadów z pośredniczkami pracy i doradczyniami zawodowymi. Jego dyrektor był więc odźwiernym (gatekeeper), to od niego uzyskiwałam zgody na rozmowy z pozostałymi osobami. Krzysztof to energiczny mężczyzna, starszy ode mnie o kilka lat, żonaty, ojciec jednego dziecka.

Zapanowanie nad rozmową z nim było trudne. Krzysztof od początku wywiadu dominował, na ogół narzucając jego tematykę. Wyraźnie chciał opowiedzieć o swoich osiągnięciach jako dyrektora urzędu i o projektach, które zainicjował, mimo że nie wszystkimi byłam zainteresowana. Początkowo wydawał się nieufny, miałam więc obawę, że może nie chcieć współpracować ze mną w formule, w której to nie on, a ja kieruję rozmową i narzucam tematy. Rezygnowałam więc z części pytań po to, żeby móc zadać te kluczowe lub takie, które wiązały się z narracją, którą on sam już rozwijał. Im dłużej trwała rozmowa, tym Krzysztof był bardziej swobodny, jego początkowa nieufność mijała. $\mathrm{W}$ pewnym momencie powiedział o tym otwarcie: „nasza relacja fajnie się otworzyła”. Dla mnie jednak wywiad był ciągłym siłowaniem się z nim: najpierw starałam się przełamać jego nieufność, potem uciąć jego próby „flirtowania” ze mną.
Po około 45 minutach rozmowy zauważyłam, że kończy się czas, który mi wcześniej wyznaczył, i powiedziałam, że postaram się zadać kilka ostatnich pytań. Odpowiedział, że ma dla mnie jeszcze czas, bo "odmawia sobie innych przyjemnych rzeczy". Chwilę później okazało się, że mieszka w tym samym budynku, w którym wynajęłam mieszkanie na czterodniowy pobyt w mieście. Wtedy Krzysztof zaproponował, że przyjdzie do mnie $z$ winem. Kilkakrotnie próbował zaprosić mnie na wieczór w pubie, mówiąc, że to tam możemy dokończyć wywiad. Wskazał wtedy obrączkę na swoim palcu, dodając: "spokojnie, jestem grzeczny". Ostatecznie umówiliśmy się na dokończenie wywiadu w urzędzie kolejnego dnia. Obawiałam się zarówno tego spotkania, jak i zostawania w wynajętym mieszkaniu. Wieczorem wysłał mi SMS-a z poradą, abym nie pracowała tak dużo, co wzbudziło mój lęk, że widział mnie przez okno (mieszkałam na parterze) i że rzeczywiście będzie próbował wprosić się do mojego pokoju. Kolejnego dnia wywiad przebiegł zaskakująco sprawnie, a na nagraniu Krzysztof brzmi rzeczowo i profesjonalnie, nie ma tam śladu jego wczorajszego "flirciarskiego" tonu. Jednak po wyłączeniu dyktafonu to się zmieniło. Zanotowałam kilka jego wypowiedzi: „dlaczego nie dajesz się podrywać?”, „dlaczego nie nosisz obrączki [skoro jesteś mężatką]?", ,jak będziesz nosić obrączkę, będziesz podrywana jeszcze bardziej” i ,jesteś feministką? Lubię feministki, z nimi jest przynajmniej jakieś partnerstwo. Moja żona nie jest feministką".

Od jego pierwszej próby „flirtu” sądziłam, że mój wyraźnie nerwowy śmiech, ignorowanie propozycji i przekierowywanie rozmowy z powrotem na sprawy merytoryczne będą wystarczającymi sygnałami sprzeciwu. Bezpośrednia odmowa wydawała mi się z kolei zbyt ryzykowna: jeśli Krzysztof od początku narzucał własne zasady interakcji, 
przeciwstawienie się mu mogło - tak mi się wtedy wydawało - zaprzepaścić moje szanse zebrania danych do studium przypadku. Badaczki, które znalazły się w podobnych sytuacjach, zazwyczaj opisują właśnie tę rozterkę: wybór pomiędzy własnym bezpieczeństwem i stawianiem granic a powodzeniem projektu (Yassour-Borochowitz 2012; Mügge 2013; Hanson, Richards 2019). Granie w grę narzuconą przez rozmówcę okazuje się efektywnym sposobem na dokończenie badania, $\mathrm{w}$ przeciwieństwie do odmowy (Wojnicka 2020). Na ogół oznacza to udział w podtrzymywaniu dobrej samooceny rozmówcy, nawet jeśli wiąże się to z przekraczaniem naszych, badaczek, granic.

Dlaczego Krzysztof mnie molestował? Dla niego nie była to strategia odzyskiwania kontroli nad sytuacją wywiadu. Rozmówca przywykł, że jako mężczyzna i zwierzchnik $\mathrm{w}$ sfeminizowanym zakładzie pracy zazwyczaj ma kontrolę i władzę. Molestowanie seksualne było jego strategią niedzielenia się nimi. Zamiast tego raczej rozszerzył jeszcze zakres swojej władzy z regulowania mojego dostępu do informacji na władzę nade mną: moim poczuciem integralności i bezpieczeństwa. Nie był wobec mnie podporządkowany tak, jak byli (w jakimś stopniu) dwaj pozostali rozmówcy, o których piszę niżej. Wywiad był dla Krzysztofa sytuacją nową i być może nie w pełni zrozumiałą, jednak od początku potrafił wykorzystać ją do swoich celów: rozbudowanej autoprezentacji, opowieści o własnych sukcesach. Dominował, a molestowanie było jedynie krokiem dalej, krokiem, który mógł zrobić, bo pozwalała mu na to jego pozycja. Wykorzystał więc nasze spotkanie do potwierdzenia i umocnienia swojego usytuowania $\mathrm{w}$ hierarchii płci. Ja z kolei byłam od niego zależna, ponieważ był on kluczowym informatorem oraz odźwiernym (gatekeeper). Z tej ostatniej pozycji szczególnie łatwo zy- skać władzę nad badaczkami i badaczami (Mügge 2013).

\section{Bogdan: poszukiwanie kontroli}

Bogdan był mężczyzną od 20 lat zarejestrowanym jako bezrobotny. Poznaliśmy się, kiedy przeprowadzałam z nim wywiad w ramach projektu dotyczącego funkcjonowania urzędów pracy. Podczas wywiadu miałam poczucie, że mimo różnic w statusie społeczno-ekonomicznym i doświadczeniu dobrze się rozumiemy i polubiliśmy się. Dlatego kilka miesięcy później skontaktowałam się z nim ponownie i zaproponowałam dalszą współpracę w ramach mojego własnego badania. Tym razem mieliśmy spotykać się nie w ośrodku pomocy społecznej, w którym Bogdan realizował staż, ale w jego domu.

Bogdan był niespełna sześćdziesięcioletnim mężczyzną mieszkającym na wsi, w pobliżu dziesięciotysięcznego miasta powiatowego. Kiedyś mieszkał w tym mieście, ale rozwód i długi sprawiły, że przeprowadził się na wieś do bardzo ubogiego domu, bez ogrzewania (z jednym piecem - kozą), kanalizacji i bieżącej wody - takie warunki mieszkaniowe spełniają kryteria bezdomności. Utrzymywał się z nieformalnej pracy dorywczej, głównie różnych prac w gospodarstwach, napraw, zbieractwa. Od czasu do czasu otrzymywał zasiłki celowe lub wynagrodzenie za udział w stażach i szkoleniach dla osób bezrobotnych. Łączne wynagrodzenie w wysokości 200 złotych, które ode mnie otrzymał za udział w badaniu, miało znaczenie w jego budżecie. Kilka naszych rozmów dotyczyło tego, jak Bogdan gospodaruje pieniędzmi, wynagrodzenie za wywiady znalazło się wśród ważnych pozycji.

Z Bogdanem kontaktowałam się kilkakrotnie w ciągu czterech miesięcy, kilka razy telefonicznie, dwa 
razy odwiedziłam go w jego domu. Dom ten leżał na skraju wsi, oddalony od pozostałych zabudowań, na końcu długiej drogi w stronę lasu. Tę drogę pokonywałam w około 20 minut z przystanku autobusowego. Pierwszy raz spotkaliśmy się w lutym. Bogdan krzątał się, co jakiś czas dorzucał drewno do kozy i przygotowywał jedzenie. O jedzeniu mówił dużo jeszcze przed moim przyjazdem, gdy rozmawialiśmy przez telefon. Planował zakupy i to, co ugotuje. Jedzenie okazało się w czasie naszych wywiadów narzędziem, za którego pośrednictwem Bogdan próbował uzyskać nade mną władzę, częstując mnie, karmiąc czy nawet wymuszając zjedzenie kolejnej bułki albo jajka na twardo. Była to ciągła próba sił, gdyż ja tymczasem uparcie powracałam $\mathrm{w}$ rozmowie do interesujących mnie wątków, co jego zdawało się czasami nudzić - moje zainteresowanie jego codziennymi czynnościami lub tym, co on nazywa praca, a czego nie było dla niego nieco niezrozumiałe. W końcu jednak akceptował moje zainteresowania i mówił chętnie, a między nami było dużo sympatii.

Relacja między badaczką a uczestnikami badania i same sytuacje wywiadów bywają niezwykle złożone. Wspomniałam już o nici porozumienia nawiązanej podczas pierwszego spotkania, późniejszym „siłowaniu się" i równoczesnym poczuciu, że mimo tego po prostu lubimy się nawzajem, ja szczerze interesuję się jego historia, a on chce mi ją opowiedzieć. Podczas wywiadów w jego domu były jednak także momenty, w których myślałam o zagrożeniu i czułam lęk. Byłam sama w domu obcego mężczyzny, w oddaleniu od innych zabudowań, w nieznanym miejscu, bez możliwości skutecznej ucieczki w razie niebezpieczeństwa. Przed wyjazdem zrobiłam to, co robi wiele badaczek wyjeżdżających w teren i co zaleca się w dokumentach dotyczących bezpieczeństwa podczas badań (Scho- ol of Anthropology and Museum Ethnography b.d.): podałam jednej osobie możliwie dokładny opis miejsca, w którym będę, i umówiłam się na kontakt o określonej godzinie. Gdybym nie odezwała się, osoba ta miała zadzwonić na policję. Przez dużą część pobytu u Bogdana czułam się dość dobrze, jednak kiedy od słowa do słowa rozmowa zeszła na jego relacje z kobietami, poczułam lęk. W tamtym momencie kilkakrotnie zapewniał mnie, że jestem z nim bezpieczna - co jedynie potęgowało moje poczucie zagrożenia, przypominało bowiem o nierównowadze sił między nami. Chodzi tu zarówno o siłę fizyczną, jak i to, na co zezwala nam kultura. Jemu, jako mężczyźnie, „wolno” na mnie wywierać presję, a nawet napastować. Mnie, jako kobiecie, „nie wolno" się bronić, powinnam być uległa. Te zasady „uprzejmości” wzmacniane są jeszcze w tego rodzaju sytuacjach przez cel i stawkę badań, podobnie jak to było w rozmowie z Krzysztofem: nie chciałam urazić informatora, wprost odmawiając mu tego, czego chce lub wyraźnie odmawiając przyjęcia jego definicji sytuacji i wystawiając go na utratę twarzy.

Była między nami jednak i innego rodzaju nierównowaga: ja płaciłam jemu, a szansa na moje kolejne wizyty oznaczała dla Bogdana kolejne wynagrodzenie. W jego sytuacji materialnej nie mógł jej zaprzepaścić, zwłaszcza w zimie, kiedy nie mógł zarabiać ze zbierania owoców leśnych lub prac gospodarskich, które wykonuje się zazwyczaj wiosną i latem. Jestem też przekonana, że Bogdan nie chciał zaprzepaścić szansy na nasze kolejne spotkanie, bo potrzebował rozmowy, empatycznego ucha i zainteresowania, które mu ofiarowałam. W tym sensie był rozmówcą wrażliwym na zranienie (vulnerable). Badaczki feministyczne podkreślają jak niski kapitał społeczny i izolacja powodują, że rozmówczynie stają się podporządkowane badaczce, często jedynej osobie, z którą mogą porozmawiać o samych sobie, 
wobec czego dzielą się intymnymi opowieściami, które zazwyczaj są raczej domeną przyjaźni (Finch 1984). Tak z pewnością było też z Bogdanem. Jego izolacja, niemal zupełny brak kontaktu z ludźmi, sprawiła, że chętnie korzystał z wyjątkowej możliwości wielogodzinnego, dość swobodnego mówienia o sobie.

Do sytuacji, którą nazywam molestowaniem seksualnym, doszło nie podczas spotkania, lecz w rozmowie telefonicznej. Podczas jednej z nich przez kilka minut bardzo zdawkowo odpowiadał na moje pytania, po czym zapytał: „a co u ciebie?”. Zazwyczaj uwaga zarówno moja jako badaczki, jak i osób uczestniczących w badaniu skupiona jest na nich, więc to wcale nieoczywiste pytanie odczytuję jako próbę odwrócenia czy zrównania ról. Odpowiedziałam powierzchownie, tym samym ignorując zalecenie Ann Oakley (1981) i metodologii feministycznej dotyczące wzajemności w wymianie informacji o sobie. $\mathrm{W}$ tamtym momencie miałam jednak poczucie, że nie mogę podporządkować się zasadom, które próbuje narzucić Bogdan, w przeciwnym razie utracę kontrolę nad wywiadem i całą relacją. Spróbowałam zadawać pytania zgodnie z interesującą mnie tematyką, na które Bogdan jednak już nie odpowiadał. Zamiast tego zaczął omawiać plany dotyczące mojej kolejnej wizyty. Mówił o tym, że mogłabym odwiedzić go w jego urodziny, które się zbliżają, dopytywał, jakie lubię wino i zaproponował, żebym tym razem została na noc, dzięki czemu nie będę musiała wychodzić tak wcześnie jak poprzednio na ostatni autobus powrotny. Oponowałam, zaznaczałam, że nie zostanę u niego na noc i próbowałam wrócić do moich pytań, nawigując między stawianiem granic a uprzejmością, aby go nie urazić. Ponownie zapewniał mnie, że nic złego mi z jego strony nie grozi i że traktuje mnie jak córkę. Jednak chwilę później zaczął kwestionować to, że jestem mężatką. Znowu pożałowałam, że nie noszę obrączki przynajmniej w pracy i po tym doświadczeniu kupiłam sobie tanią obrączkę - wybieg bardzo często stosowany przez badaczki terenowe (Mügge 2013).

Przez kilka tygodni zastanawiałam się, w jaki sposób rozwiązać tę sytuację: czy kontynuować badanie i relację z Bogdanem? W końcu zdecydowałam się uwzględnić raczej moje własne granice i poczucie bezpieczeństwa. Zadzwoniłam do niego ponownie, tym razem po to, żeby oznajmić mu, że już się nie spotkamy. Postanowiłam o zmianie lokalizacji dalszego badania. Nie wyjaśniłam jednak, że decyzja ta wynika z tego, w jakim kierunku rozwinęła się nasza relacja.

Zachowanie Bogdana podczas rozmowy telefonicznej spełnia kryteria molestowania seksualnego. Były to niechciane, nachalne propozycje i sugestie o podtekście seksualnym. Mimo że była to rozmowa telefoniczna, czułam się zagrożona. Bogdan nie tyle podważył, co zupełnie zignorował moją rolę $\mathrm{w}$ naszej relacji, próbując przeformułować ją od nowa - z rodzaju kontraktu między badaczką a uczestnikiem badania ${ }^{7}$ z pewnymi zadaniami, celami i współpracą opartą na sympatii - na relację całkowicie prywatną i romantyczną. Gra toczyła się o to, czyje cele i potrzeby zostaną unieważnione, a czyje zrealizowane: moje - profesjonalne czy jego - relacyjne i romantyczne. Była to więc strate-

\footnotetext{
7 Taki charakter dodatkowo podkreślać miało wynagrodzenie i formalności: potwierdzenie odbioru wynagrodzenia, pisemna zgoda na udział w badaniu, pisemna informacja o badaniu i możliwości złożenia na mnie skargi. W tym przypadku jednak wszystkie te elementy miały spowodować formalizację naszej relacji i przyjęcie przez Bogdana roli ",profesjonalnego” uczestnika badania. Być może jego zachowanie wobec mnie i próby skierowania naszych kontaktów ku celom zupełnie nieformalnym i romantycznym były też obroną przeciw takiej formalizacji.
} 
gia Bogdana, w której spróbował zyskać nie władzę, a kontrolę nad naszą relacja, wychodząc z pozycji podporządkowanej. To ja zazwyczaj miałam nad nim przewagę: regulowałam częstotliwość kontaktu, dysponowałam wynagrodzeniem, którego potrzebował i - jak się na koniec okazało - mogłam przerwać relację w każdym momencie. Miałam do tego kompetencje i odpowiednie dyspozycje: moja asertywność w tej sytuacji wynikała także z różnicy klasowej między nami.

Waham się, nazywając jego zachowanie molestowaniem, ponieważ wynikało ono, jak sądzę, w pierwszej kolejności nie z tego, że Bogdan jest starszym mężczyzną, który może skorzystać z władzy nad młodszą kobietą dzięki własnemu usytuowaniu w hierarchii płci (wzmocnionym jeszcze przewagą związaną z wiekiem), lecz z jego autentycznej i głębokiej potrzeby bliskości i przyjaźni. Mimo że nasze interakcje były próbą sił i grą o stawki, strategia Bogdana dotyczyła raczej uzyskania kontroli, a nie władzy. Dążył, jak sądzę po długim czasie, w którym nauczyłam się z empatią myśleć o jego usytuowaniu w naszej relacji, do układu bardziej partnerskiego, w którym jego potrzeby emocjonalne byłyby zrealizowane obok moich potrzeb poznawczych. Przyjął do tego strategię, którą podpowiadały $\mathrm{mu}$ nasze pozycje $\mathrm{w}$ hierarchii płci: uczynił ze mnie obiekt pragnienia i poinformował mnie o tym w sposób natarczywy i zagrażający. Przekroczył moje granice i w konsekwencji całkowicie wycofałam się z relacji.

\section{Jacek: władza w małżeńskiej diadzie}

Jacek był uczestnikiem badania dotyczącego wymiarów wykluczenia społecznego. Wziął udział w wywiadzie grupowym z młodymi mężczyznami, bezrobotnymi mieszkańcami około dwu- dziestotysięcznego miasta z bardzo wysoką stopą bezrobocia. Wraz z koleżanką wytypowałyśmy go spośród uczestników do wywiadu biograficznego ze względu na jego trudną historię. Jacek chorował na raka i epilepsję. $W$ związku z tym nie mógł wykonywać wielu prac i miał trudności ze znalezieniem legalnego zatrudnienia. Badanie realizowałam w 2013 roku jako młoda, niedoświadczona badaczka rozpoczynająca studia doktoranckie. W związku z tym, że minęło kilka lat, sytuację tę rekonstruuję na podstawie notatek i z pamięci, ze świadomością, że moja pamięć zniekształciła ją oraz że o wielu detalach nie pamiętam. Dlatego poniżej opisuję jedynie te momenty, co do których mam pewność, że pamiętam je wystarczająco dobrze, między innymi dzięki temu, że zaraz po tym zdarzeniu i w kolejnych latach opowiadałam o nich innym osobom.

Wywiad z Jackiem odbył się w jego mieszkaniu, w którym równocześnie była jego żona, Katarzyna, i małe dzieci. Przez większość czasu drzwi do pokoju, w którym byliśmy, były otwarte i z mieszkania dobiegały głośne hałasy: krzyczące dzieci, krzątająca się partnerka. Jedno z dzieci bardzo chciało zostać z ojcem, o co przez jakiś czas toczyły się negocjacje. $\mathrm{W}$ pewnym momencie cała rodzina była już z nami, a żona przysłuchiwała się wywiadowi, a nawet w nim uczestniczyła. Na domiar złego przed wywiadem musiałam poinformować Jacka, że zapomniałam zabrać ze sobą bon zakupowy, który stanowił wynagrodzenie za udział w badaniu. Zapewniałam, że wyślę go niezwłocznie pocztą. Wzbudziłam tym jego nieufność i zniecierpliwienie - wynagrodzenie było dla niego wyraźnie najważniejszą motywacją do udzielenia wywiadu. Jacek kilkakrotnie wracał do tematu, dopytując, czy na pewno je otrzyma. W tych chwilach byłam skruszoną, przepraszającą studentką, która przez własną 
nieuwagę nie dopełniła ważnego zobowiązania. $\mathrm{W}$ ten sposób straciłam szansę zapanowania nad wywiadem, zanim jeszcze się zaczął.

W Jacku było dużo gniewu. Chaotycznie i gwałtownie opowiadał o trudnościach $\mathrm{w}$ znalezieniu pracy. Żona dopowiadała i wyjaśniała, że Jacek, będąc chorym, nie dostaje zgód od lekarzy medycyny pracy na wykonywanie tych zawodów, które byłyby w jego zasięgu, czyli prostych prac fizycznych.

Badanie prowadziłam w czasie, w którym rząd, nowelizując ustawę, odebrał świadczenie pielęgnacyjne opiekunkom i opiekunom osób z niepełnosprawnościami, których niepełnosprawność powstała po 18 roku życia ${ }^{8}$. Katarzyna do tej pory otrzymywała właśnie to świadczenie, więc dochód ich rodziny znacznie się zmniejszył. Oboje byli tym sfrustrowani. Kiedy jednak Jacek mówił o tym z gniewem i złorzeczył pracownicom socjalnym, burmistrzowi i urzędnikom miejskim (których oskarżał o kradzieże środków dla potrzebujących), Katarzyna była pragmatyczna. Wypytywała mnie o zmiany w ustawie i o moją interpretację tych zmian. Wyraźnie to ona była organizatorką życia rodziny, jej wydatków i źródeł dochodu. To ona, nie Jacek, prowadziła ze mną dość rzeczową rozmowę, w ten sposób odbierając mężowi kontrolę nad tym spotkaniem i usuwając go na drugi plan. Ja z kolei próbowałam nawigować między ich dwójką tak, aby uzyskać od nich obojga jak najwięcej informacji o biografii i sytuacji życiowej Jacka.

\footnotetext{
${ }^{8}$ Chodzi o nowelizację ustawy o świadczeniach rodzinnych z 7 grudnia 2012 r. Ograniczono w niej grupę uprawnionych do świadczenia pielęgnacyjnego do osób opiekujących się osobami, których niepełnosprawność powstała nie później niż do ukończenia 18. roku życia lub w trakcie nauki w szkole lub w szkole wyższej, ale nie później niż do ukończenia 25. roku życia. Wcześniej wiek, w którym osoba nabyła niepełnosprawność, nie miał znaczenia dla uprawnienia jej opiekuna lub opiekunki do pobierania tego świadczenia.
}

Jacek coraz więcej uwagi poświęcał przytulającemu się do niego synowi. „Podoba ci się ta pani?” - zapytał go, uśmiechając się do mnie dwuznacznie. „Mi też się podoba”. W końcu zwrócił się do mnie: „Czy da mi pani swoje zdjęcie, żebym mógł sobie na nie czasem popatrzeć?". Wymieniłyśmy z Katarzyną szybkie zaniepokojone spojrzenia. Roześmiałam się i spróbowałam kontynuować wywiad, który zbliżał się już do końca. Jacek jednak wyraźnie nie chciał już w nim uczestniczyć i zamiast tego prawił mi dalsze komplementy. Jego żona nie odezwała się więcej. Obie byłyśmy w tej sytuacji podporządkowane Jackowi, któremu nie mogłyśmy się sprzeciwić. Ja byłam związana uprzejmością wobec uczestnika badania, ona - wobec gościa, czyli mnie. Obie więc przyjęłyśmy typowe kobiece role. Molestując mnie, Jacek skorzystał ze swojej męskiej władzy, którą jednak miał nie tylko nade mną, ale też nad swoją żoną. To Katarzyna, jak się zdaje, była jego celem, ja byłam jedynie pośredniczką, narzędziem w upokorzeniu żony i wskazaniu jej miejsca w ich związku. Była to reakcja Jacka na dynamikę naszego spotkania, podczas którego został zepchnięty przez żonę, bardziej kompetentną rozmówczynię, na drugi plan. Być może też upokorzenie żony było jego zwykłą strategią odwetu za własne podporządkowanie - nie mógł bowiem uzyskać tradycyjnej męskiej przewagi, pełniąc rolę żywiciela rodziny. Podobnie jak Bogdan odwołał się więc do tej hierarchii, która była mu dostępna i w której posiadał przywileje, to jest hierarchii płci.

\section{Wnioski: kierunki dla akademii}

Podejście, które tu proponuję, to jest wykorzystanie trudnych doświadczeń molestowania seksualnego (lub innego rodzaju przemocy) w terenie jako danych, nie ma normalizować przemocy, nie ma wzmacniać etnograficznych fiksacji. Analizu- 
jąc molestowanie seksualne jako strategie mężczyzn podczas wywiadu, starałam się zrobić użytek z wydarzeń, których nie chciałam doświadczyć, lecz w danych momentach bezsilności nie czułam, że mam wybór. Tekst ten, jak wiele innych o tej tematyce, ma przyczynić się do łamania tabu i tworzenia języka, którym możliwe będzie mówienie o trudnych doświadczeniach w terenie. Ma też zwrócić uwagę na problem bezpieczeństwa i przemocy podczas realizacji badań. Ma w końcu zawalczyć z przekonaniem, że niektóre doświadczenia i słowa są „niedozwolone” w pisarstwie akademickim. Przeciwnie, wszelkie doświadczenia badaczek podczas realizacji badań są częścią terenu, mają znaczenie w procesie wytwarzania wiedzy i mogą stanowić dane, informacje podlegające interpretacji.

Skoro badania jakościowe wiążą się z ryzykiem doświadczenia seksizmu, homofobii i innych wymiarów dyskryminacji oraz $\mathrm{z}$ wystawieniem na przemoc i zagrożenie, doświadczenia te powinny znaleźć swoje miejsce $\mathrm{w}$ etnograficznych reprezentacjach. Działania zmierzające do zwiększenia bezpieczeństwa osób prowadzących badania muszą zmierzać do dekonstrukcji i rozbrojenia etnograficznych fiksacji na poziomie ideologicznym i praktycznym. Na poziomie ideologicznym byłoby to włączenie mniejszościowych narracji i upowszechnianie relacji $\mathrm{z}$ terenu, $\mathrm{w}$ których pojawiają się opisy trudnych doświadczeń - i uwzględnianie ich jako równoprawnych danych. Nie są to bowiem doświadczenia wynikające z „prywatnej” tożsamości badaczek, lecz trudna część ich profesjonalnej działalności.

Na poziomie praktycznym instytucje kształtujące i zatrudniające badaczki i badaczy powinny stwarzać systemy wsparcia dla osób doświadczających przemocy podczas realizacji badań. Byłaby to re- alizacja kodeksowego zobowiązania pracodawcy do przeciwdziałania dyskryminacji i zapewnienia bezpiecznych warunków pracy ${ }^{9}$ Amy Pollard (2009) proponuje mentoring, opiekę starszych doktorantów i doktorantek nad młodszymi oraz odpowiednie przygotowanie opiekunów i opiekunek naukowych. Z kolei będąc współorganizatorką półformalnej grupy wsparcia, wiem, że regularne spotkania w niehierarchicznej grupie są wyjątkowo pomocne $\mathrm{w}$ radzeniu sobie $\mathrm{z}$ bieżącymi trudnościami w pracy naukowej, a dyskusja pomaga je znormalizować i urefleksyjnić właśnie jako element pola badawczego. Tego rodzaju spotkania odbywają się też $\mathrm{w}$ gronie międzynarodowym, w związku z powstającą siecią wsparcia dla badaczek terenowych. Sieć ta ma organizować kontakt z osobami i organizacjami w różnych miejscach na świecie, do których można zwrócić się po pomoc w trudnych sytuacjach ${ }^{10}$.

Ważne, aby działania instytucjonalne nie stały się fasadowymi formalnościami. Doświadczenia badaczek z innych krajów, na przykład z uniwersytetów brytyjskich, pokazują, że formularze oceny ryzyka, które pozornie mają przygotować badaczy i badaczki do trudności w terenie, w rzeczywistości służą instytucjom do ochrony przed pozwami o odszkodowania. Podobnie mimo coraz bardziej powszechnych na zachodnich uczelniach kodeksów i poradników przeznaczonych dla opiekunów naukowych i promotorek (a uwzględniających wsparcie dla podopiecznych doświadcza-

\footnotetext{
${ }_{9}^{9}$ Ustawa z dnia 26 czerwca 1974 r. Kodeks pracy, art. 94 (Dz.U. 1974, nr 24, poz. 141).

${ }^{10}$ Chodzi o comiesięczne Spotkania Badaczek współorganizowane przeze mnie wraz z Katarzyną Dębską przy Wydziale Socjologii UW oraz o sieć Women Doing Fieldwork zainicjowaną przez dr Anę Laurę Zavalę Guillén z University of Birmingham oraz doktorantki Itzel San Roman Pinedę i Jennifer Lidia Veenstra z University of Sheffield.
} 
jących przemocy w terenie), wiele $\mathrm{z}$ nich wciąż nie potrafi prawidłowo i empatycznie odnieść się do relacji młodszych koleżanek, w tym własnych doktorantek, o molestowaniu seksualnym. Młode badaczki często nie mają nawet poczucia, że mogą o tych doświadczeniach opowiedzieć opiekunom, zwłaszcza mężczyznom, którym z racji ich własnej pozycji w hierarchii płci brakuje wyobraźni, by odpowiednio zareagować. Tymczasem doświadczenia te uzasadniają ich decyzje na przykład o wycofaniu się z danej lokalizacji lub terenu w ogóle. W tych sytuacjach badaczki szukają innych, „oficjalnych” uzasadnień, pozostając z poczuciem unieważnienia własnych doświadczeń. Z kolei próby otwartych rozmów kończą się niekiedy lekceważącymi i krzywdzącymi uwagami o przewrażliwieniu lub winie samej badaczki (zob. też np. Moreno 1995; Kloß 2017). Powyższe uwagi, spisane na podstawie dyskusji w międzynarodowym gronie akademiczek, pokazują nietrafność lub niedostateczność niektórych rozwią-

\section{Bibliografia}

Arendell Terry (1997) Reflections on the Researcher-Researched Relationship: A Woman Interviewing Men. "Qualitative Sociology", vol. 20, no. 3, s. 341-368.

Bielenin-Lenczowska Karolina (2013) Trudne tematy, trudne badania. O wielostanowiskowej etnografii wśród macedońskich Muzutmanów (Torbeszów) w Macedonii $i$ we Włoszech [w:] Inga Kuźma, red., Tematy trudne. Sytuacje badawcze. Łódź: Wydawnictwo Uniwersytetu Łódzkiego, s. 49-63.

Bielenin-Lenczowska Karolina (2015) Spaghetti z ajwarem. Translokalna codzienność muzułmanów w Macedonii i we Włoszech. Warszawa: Wydawnictwa Uniwersytetu Warszawskiego.

Cotterill Pamela (1992) Interviewing women. Issues of Friendship, Vulnerability, and Power. „Women's Studies International Forum", vol. 15, no. 5-6, s. 593-606. zań. Polska akademia może wzorować się na nich w sposób bardziej refleksyjny.

Problem molestowania seksualnego $\mathrm{w}$ terenie jest mało obecny w polskojęzycznej literaturze etnograficznej i socjologicznej. Wydaje się, że bezpieczeństwo i dobrostan badaczek i badaczy pozostają wciąż na trzecim planie w stosunku do zobowiązań wobec uczestników i uczestniczek badań oraz konieczności realizacji badania. Jeśli jednak etnograficzne fiksacje mają zostać zdekonstruowane i rozbrojone także w polskiej akademii, potrzebujemy języka do opisu trudnych doświadczeń badawczych. Proces ten powinien odbywać się na poziomie kształcenia, rozmów ze studentkami i studentami. Problem przemocy doświadczanej podczas badań wymaga oswojenia przez społeczność akademicką tak, aby możliwe było otwarte mówienie o trudnych i zagrażających zdarzeniach, szukanie i dawanie wsparcia (w tym instytucjonalnego) oraz, w miarę możliwości, przygotowanie do takich doświadczeń $\mathrm{w}$ pracy terenowej.

Edwards Rosalind (1990) Connecting method and epistemology: A white woman interviewing black women. „Women's Studies International Forum", vol. 13, no. 5, s. 477-490.

Finch Janet (1984) "It's great to have someone to talk to": the ethics and politics of interviewing women [w:] Colin Bell, Helen Roberts, eds., Social Researching: Politics, Problems, Practice. London: Routledge and Kegan Paul, s. 70-86.

Fine Gary Alan (1993) Ten Lies of Ethnography: Moral Dilemmas in Field Research. "Journal of Contemporary Ethnography", vol. 22, no. 3, s. 267-294.

Gailey Jeannine A., Prohaska Ariane (2011) Power and gender negotiations during interviews with men about sex and sexually degrading practices. "Qualitative Research", vol. 11, no. 4, s. 365-380. 
Gearing Jean (1995) Fear and loving in the West Indies: Research from the heart (as well as the head) [w:] Dan Kulick, Margaret Wilson, eds., Taboo: Sex, Identity, and Erotic Subjectivity in Anthropological Fieldwork. London, New York: Taylor \& Francis Routledge, s. 186-218.

Golczyńska-Grondas Agnieszka (2019) Wywiady biograficzne z osobami ze środowisk wykluczenia społecznego - refleksja nad wybranymi problemami metodologicznymi i etycznymi. „Przegląd Socjologii Jakościowej", t. 15, nr 2, s. 178-20.

Green Gill i in. (1993) "Who wears the trousers?" Sexual Harassment in Research Settings. „Women's Studies International Forum", vol. 16, no. 6, s. 627-637.

Grębecka Zuzanna (2016) Legnickie opowieści o PRL-u. Prowadzenie wywiadu etnograficznego jako praktyka profesjonalna $i$ międzyludzka [w:] Grzegorz Godlewski, Agnieszka Karpowicz, Marta Rakoczy, red., Antropologia praktyk językowych. Warszawa: Wydawnictwa Uniwersytetu Warszawskiego, s. 298-324.

Hanson Rebecca, Richards Patricia (2017) Sexual Harassment and the Construction of Ethnographic Knowledge. "Sociological Forum", vol. 32, no. 3, s. 587-609.

Hanson Rebecca, Richards Patricia (2019) Harassed. Gender, bodies and ethnographic research. Oakland, CA: University of California Press.

Hryciuk Renata Ewa (2009) Od córki do profesjonalistki. Obserwacja uczestniczaca w antropologii: dylematy, ograniczenia $i$ zaskoczenia na przykładzie badań terenowych w mieście Meksyk [w:] Barbara Wagner, Tomasz Wiślicz, red., Obserwacja uczestniczaca w badaniach historycznych. Zabrze: Oficyna Wydawnicza Inforteditions, s. 53-74.

Kloß Sinah Theres (2017) Sexual(ized) harassment and ethnographic fieldwork: A silenced aspect of social research. "Ethnography", vol. 18, no. 3, s. 396-414.

Kość-Ryżko Katarzyna E. (2013) Etnolog w labiryncie znaczeń kulturowych. Psychologiczne wyzwania badań terenowych [w:] Inga Kuźma, red., Tematy trudne. Sytuacje badawcze. Łódź: Wydawnictwo Uniwersytetu Łódzkiego, s. 15-47.

Kubisa Julia (2005) O molestowaniu seksualnym w miejscu pracy w Polsce. „Humanizacja Pracy”, nr 4-5, s. 59-69.

Kulick Dan (1995) Introduction. The sexual life of anthropologists: erotic subjectivity and ethnographic work [w:] Dan Kulick, Margaret Willson, eds., Taboo: Sex, Identity, and Erotic Subjectivity in
Anthropological Fieldwork. London, New York: Taylor \& Francis Routledge, s. 1-28.

Kulick Don, Willson Margaret, eds. (1995) Taboo: Sex, Identity, and Erotic Subjectivity in Anthropological Fieldwork. London, New York: Taylor \& Francis Routledge.

Lee Deborah (1997) Interviewing Men: Vulnerabilities and Dilemmas. „Women's Studies International Forum”, vol. 20, no. 4, s. 553-564.

Limerick Brigid, Burgess-Limerick Tracey, Grace Margaret (1996) The politics of interviewing: Power relations and accepting the gift. „International Journal of Qualitative Studies in Education", vol. 9, no. 4, s. 449-460.

McLuhan Arthur (2020) Feigning Incompetence in the Field. "Qualitative Sociology Review", vol. 16(2), s. 62-67.

Męcfal Sylwia (2016) Badacz zjawisk "trudno dostępnych" w terenie - kwestie etyczne, praktyczne i metodologiczne. "Przegląd Socjologii Jakościowej", t. 12, nr 3, s. 88-101.

Moreno Eva (1995) Rape in the field. Reflections from a survivor [w:] Dan Kulick, Margaret Willson, eds., Taboo: Sex, Identity, and Erotic Subjectivity in Anthropological Fieldwork. London, New York: Taylor \& Francis Routledge, s. 219-250.

Mügge Lisa M. (2013) Sexually harassed by gatekeepers: Reflections on fieldwork in Surinam and Turkey. "International Journal of Social Research Methodology", vol. 16, no. 6, s. 541-546.

Newton Esther (1993) My Best Informant's Dress: The Erotic Equation in Fieldwork. "Cultural Anthropology”, vol. 8, no. 1, s. 3-23.

Oakley Ann (1981) Interviewing women: a contradiction in terms [w:] Helen Roberts, ed., Doing Feminist Research. London: Routledge and Kegan Paul, s. 30-61.

Oakley Ann (2015) Interviewing Women Again: Power, Time and the Gift. „Sociology”, vol. 50, no. 1, s. 195-213.

Pini Barbara (2005) Interviewing men: Gender and the collection and interpretation of qualitative data. "Journal of Sociology", vol. 41 , no. 2, s. 201-216.

Pollard Amy (2009) Field of screams: difficulty and ethnographic fieldwork. „Anthropology Matters”, vol. 11, no. 2, s. 1-24.

Ribbens Jane (1989) Interviewing - an „unnatural situation"? „Women's Studies International Forum", vol. 12, no. 6, s. 579-592. 
Riessman Catherine Kohler (1987) When gender is not enough: Women interviewing women. "Gender and Society", vol. 1, no. 2, s. 172-207.

School of Anthropology and Museum Ethnography, University of Oxford (brak daty) Safe interviewing guidelines [dostęp 1 lutego 2021 r.]. Dostępny w Internecie: ‘https://www.anthro. ox.ac.uk/safety-fieldwork-and-ethics\#collapse389441.

Sharp Gwen, Kremer Emily (2006) The Safety Dance: Confronting Harassment, Intimidation, and Violence in the Field. "Sociological Methodology", vol. 36, s. 317-327.

Smith Dorothy E. (1990) The conceptual practices of power. A feminist sociology of knowledge. Boston: Northeastern University Press.

Smith Dorothy E. (2005) Institutional ethnography. A sociology for people. Lanham, New York, Toronto, Oxford: AltaMira Press.

Solnit Rebecca (2017) Mężczyźni objaśniaja mi świat. Przełożyła A. Dzierzgowska. Kraków: Wydawnictwo Karakter.

Stacey Judith (1988) Can there be a feminist ethnography? „Women's Studies International Forum", vol. 11, no. 1, s. 21-27.
Steffen Megan (2017) Doing Fieldwork After Henrietta Schmerler On Sexual Violence and Blame in Anthropology. "American Ethnologist Website", November 13 [dostęp 13 lutego 2021 r.]. Dostępny w Internecie: ‘https://americanethnologist.org/features/ reflections/doing-fieldwork-after-henrietta-schmerler».

Surmiak Adrianna (2016) Wybrane problemy etyczne w naukowych badaniach na zlecenie. Refleksje etnografki. „Przegląd Socjologii Jakościowej", t. 12, nr 3, s. s. 120-134.

Tang Ning (2002) Interviewer and Interviewee Relationships Between Women. „Sociology”, vol. 36, no. 3, s. 703-72.

Wojnicka Katarzyna (2020) Sex and the Fieldwork: Gender, Sexuality, Nationality, and Social Class in Research on European (Heterosexual) Men. „International Journal of Qualitative Methods", vol. 19 [dostęp 10 maja 2021 r.]. Dostępny w Internecie 〈https://journals.sagepub.com/doi/ full/10.1177/1609406920938964>.

Yassour-Borochowitz Dalit (2012) "Only if she is sexy": An autoethnography of female researcher-male participants relations. „Equality, Diversity and Inclusion: An International Journal”, vol. 31, no. 5-6, s. 402-417.

\section{Cytowanie}

Palęcka Alicja (2021) „Spokojnie, jestem grzeczny”. Molestowanie seksualne jako strategia uczestników badania. "Przegląd Socjologii Jakościowej", t. 17, nr 2, s. 44-60 [dostęp dzień, miesiąc, rok]. Dostępny w Internecie: «www.przegladsocjologiijakosciowej.org〉. DOI: https://doi.org/10.18778/1733-8069.17.2.03

\section{'Not to Worry, I'm Well-Behaved': Sexual Harassment as a Strategy of the Research Participants}

The aim of the article is to make visible the violence experienced by researchers in the field. Firstly, violence is sometimes a part of the fieldwork and as such can be analyzed. Secondly, keeping quiet about it strengthens the harmful aspects of the academic culture, in which the problems related to belonging to minority groups (including the problems of women in academia) remain invisible. As a consequence, research institutions do not develop support mechanisms for people experiencing violence, and researchers are not prepared for this kind of difficulty. I analyze three incidents of sexual harassment that I myself have experienced in the field. I interpret them as one of the strategies adopted by research participants during an interview to gain power or control over the situation.

Keywords: sexual harassment, research field, academic culture, research participants' strategies 